\title{
Hubungan Kebiasaan Sarapan dan Asupan Zat Gizi dengan Status Gizi Siswi SMAN 3 Surabaya
}

\section{Correlation between the Habit of Eating Breakfast, Nutrient Intake and Nutritional Status of Female Students in SMAN 3 Surabaya}

\author{
Whenny Irdiana* ${ }^{1}$, Triska Susila Nindya ${ }^{2}$
}

\begin{abstract}
ABSTRAK
Latar Belakang: Kebiasaan makan pada masa remaja dapat berdampak pada kesehatan terutama masalah gizi pada fase kehidupan yang akan datang yaitu saat dewasa dan berusia lanjut. Banyak remaja masih melewatkan waktu makan dan mengkonsumsi makanan yang tidak seimbang.

Tujuan: Penelitian ini bertujuan untuk mengetahui hubungan antara kebiasaan sarapan dan asupan zat gizi dengan status gizi pada siswi SMAN 3 Surabaya.

Metode: Desain penelitian yang digunakan adalah cross sectional. Populasi dalam penelitian ini adalah semua siswi kelas X dan XI SMAN 3 Surabaya yang berjumlah 444 orang. Sebanyak 80 siswi dipilih menjadi sampel dengan menggunakan Simple random sampling. Data yang dikumpulkan meliputi kebiasaan sarapan dengan wawancara langsung menggunakan kuisioner, asupan zat gizi diperoleh dengan metode food recall $2 \times 24$ jam, dan status gizi ditentukan berdasarkan pengukuran IMT/U.

Hasil: berdasarkan hasil penelitian diketahui sebagian besar dari responden belum memiliki kebiasaan sarapan setiap hari dan asupan gizi makro pada responden rata-rata masih belum sesuai dengan anjuran. Selain itu, terdapat responden dengan gizi lebih dan gizi kurang meskipun sebagai besar dari mereka memiliki status gizi normal. Hasil dari uji korelasi Spearman, menunjukan bahwa tidak ada hubungan yang signifikan antara kebiasaan sarapan dengan status gizi $(p=0,402)$, namun siswi yang tidak sarapan cenderung memiliki gizi lebih. Hasil pada penelitian ini juga menunjukan bahwa tidak ada hubungan yang signifikan antara asupan zat gizi energi $(p=0,811)$, karbohidrat $(p=0,696)$, protein $(p=0,970)$ dan lemak $(p=0,816)$ dengan status gizi.

Kesimpulan: Tidak adanya hubungan antara kebiasaan sarapan dan asupan zat gizi dengan status gizi dapat disebabkan oleh faktor lain seperti jumlah anggota keluarga, pendapatan keluarga dan penyakit.
\end{abstract}

Kata Kunci: kebiasaan sarapan, asupan zat gizi, dan status gizi 


\begin{abstract}
Background: Eating habit in adolescence will give an impact on health, especially nutritional problems in the next phase of life that is in adulthood and old age. Many teenagers are still skipping meals and eating imbalance foods.

Objectives: This study is aimed to determine the relationship between breakfast habit and nutrient intake with nutritional status of female students in SMAN 3 Surabaya.

Method: Research design used was cross sectional. Population of this research is all female students of class $X$ and XI SMAN 3 Surabaya as many as 444 people. Eighty students was choosen using simple random sampling method. The data that had been collected included breakfast habits which gained by direct interview using questionnaire, nutrient intake that was obtained by $2 \times 24$ hours food recall method, and nutritional status was determined based on BMI for Age measurement.

Results: It is known that most of the respondents do not have daily breakfast habit and macronutrient intake on the average of respondent still not in accordance with the suggestion. In addition, there were respondents with overweight dan underweight, although most of them had normal nutritional status. Results of Spearman correlation test showed no significant relationship between breakfast habit and nutritional status $(p=0.402)$, but female students who skipped breakfast tend to be overweight. The result of this research showed that no correlation between nutrient intake of energy $(p=0.811)$, carbohydrates $(p=0.696)$, protein $(p=0.970)$ and fat $(p=0.816)$ with nutritional status.

Conclusion: The unsignificant results between breakfast habit and macronutrient intake with nutritional status could be caused by several factors, such as the number of family members, income and health issue.
\end{abstract}

Keywords: breakfast habit, nutritional intake, and nutritional status

\footnotetext{
*Koresponden:

whenny.irdiana@yahoo.com

${ }^{1}$ Departemen Gizi Kesehatan, Fakultas

Kesehatan Masyarakat-Universitas Airlangga
} 


\section{PENDAHULUAN}

Pada masa remaja terjadi banyak perubahan yang dapat berlangsung cepat seperti pertumbuhan fisik, kognitif, dan psikososial atau tingkah laku ${ }^{1}$. Tahap periode terjadi puncak pertumbuhan yaitu pada masa remaja. Puncak pertumbuhan akan mempengaruhi perubahan komposisi tubuh, pertumbuhan yang pesat pada berat badan dan masa tulang, dan aktifitas fisik, sehingga mempengaruhi kebutuhan gizi pada remaja akhir ${ }^{2}$.

Pada masa remaja masalah gizi yang dapat terjadi yaitu gizi kurang, gizi lebih dan obesitas ${ }^{3}$. Saat ini di Indonesia prevalensi kurus pada remaja usia 13-15 tahun sebesar $(11,1 \%)$ dan prevalensi gemuk sebesar $(10,8 \%)$. Pada remaja usia 16-18 tahun prevalensi kurus sebesar $(9,4 \%)$ dan prevalensi gemuk sebesar (7,3\%). Provinsi Jawa Timur termasuk Provinsi dengan prevalensi gemuk di atas Nasional pada remaja usia 13-18 tahun. Prevalensi kurus relatif sama tahun 2007 dan 2013 , dan prevalensi sangat kurus naik $(0,4 \%)$ sebaliknya prevalensi gemuk naik dari $(1,4 \%)$ pada tahun 2007 menjadi $(7,3 \%)$ pada tahun $2103^{4}$.

Kota Surabaya merupakan salah satu kota di Jawa Timur yang memiliki prevalensi sangat kurus $(1.0 \%)$, kurus $(5,5 \%)$, gemuk $(7,7 \%)$ dan obesitas $(2,2 \%)$ pada perempuan usia 16-18 tahun yang dilihat berdasarkan IMT/U. Saat ini prevalensi kekurangan energi kronis (KEK) pada penduduk wanita usia subur (WUS) berusia 15-19 tahun di Jawa Timur sebesar $44 \%$ bagi wanita hamil dan $52,5 \%$ bagi wanita tidak hamil ${ }^{5}$.

Remaja melakukan berbagai upaya untuk menurunkan berat badan atau mempertahankan status gizi, salah satu upaya tersebut adalah dengan melewatkan sarapan ${ }^{6}$. Hasil penelitian yang telah dilakukan oleh Ethasari pada tahun 2014 menunjukan bahwa $(30,4 \%)$ anak jarang sarapan dan $(5,4 \%)$ tidak pernah sarapan ${ }^{7}$. Padahal, sarapan memiliki peranan penting terutama bagi anak yang bersekolah. Sarapan dapat membantu dalam kosentrasi belajar disekolah sehingga, dapat medukung prestasi belajar serta dapat memenuhi kebutuhan gizi untuk aktivitas yang padat di sekolah ${ }^{8}$.

Sebagian remaja meninggalkan sarapan merupakan hal yang biasa 7 . Menurut pendapat remaja putri, makan pagi dan makan malam adalah faktor utama penyebab tubuh menjadi gemuk. Selain itu, menurut mereka faktor lain yang dapat menjadi alasan saat melewatkan waktu makan diantaranya yaitu dirumah tidak tersedia pangan untuk dikonsumsi, pangan tidak menarik untuk disantap, pangan yang disediakan membosankan dan tidak memiliki bayak waktu (waktu terbatas) karena harus berangkat pagi ke sekolah. Remaja yang tinggal di perkotaan seingkali melewatkan waktu makan terutama makan pagi yang disebabkan oleh kesibukan ibu bekerja dan waktu yang terbatas karena harus segera meninggalkan rumah di pagi hari ${ }^{6}$.

Penelitian yang telah dilakukan oleh Zuhdy tahun 2015, masalah gizi banyak ditemui pada remaja putri dimana sebagian besar jenis makanan yang sering dikonsumsi oleh remaja putri SMA yaitu camilan $(77,3 \%)$ dan fast food $(94,7 \%)^{9}$. Camilan dan fast food mengandung kalori yang tinggi namun sedikit mengandung zat gizi yang dibutuhkan oleh tubuh. Didukung dengan penelitian yang dilakukan Widianti tahun 2012 di SMA Theresiana Semarang menunjukan bahwa sebagian besar remaja putri tidak makan secara teratur yang artinya mereka belum menjalankan perilaku makan yang baik, hal ini dapat dilihat dari hasil prosentase Widianti yang menunjukan remaja putri yang melewatkan waktu makan (56,9\%) ${ }^{10}$. Penelitian yang dilakukan oleh Haq pada tahun 2014 juga menunjukan bahwa dalam sehari sebagian besar remaja putri $(67,8 \%)$ memiliki frekuensi makan kurang dari 3 kali $^{2}$.

Ketidakseimbangan konsumsi dan kebutuhan zat gizi pada dasarnya berawal dari pemahaman yang keliru dan perilaku gizi yang salah sehingga dapat menimbulkan masalah gizi pada remaja ${ }^{9}$. Remaja merupakan generasi penerus bangsa terutama pada remaja putri yang akan menjadi calon ibu dikelak kemudian hari. Keadaan gizi pada remaja putri dapat berpengaruh terhadap kehamilannya kelak, juga terhadap bayi yang 
akan dilahirkannya. Oleh karena itu, berdasarkan latar belakang yang telah diuraikan diatas peneliti tertarik untuk melakukan penelitian terkait dengan kebiasaan sarapan dan asupan zat gizi dengan status gizi. Penulis menetapkan untuk mengambil sampel penelitian di SMAN 3 Surabaya, karena sekolah tersebut belum pernah dilakukan penelitian mengenai status gizi pada siswinya.

\section{METODE}

Penelitian yang dilakukan oleh peneliti merupakan penelitian analitik yang bersifat observasional dengan menggunakan pendekatan cross sectional yang dilaksanakan di SMAN 3 Surabaya. Populasi dalam penelitian ini adalah siswi kelas $\mathrm{X}$ dan $\mathrm{XI}$ sebanyak 444 siswi. Subyek yang dibutuhkan dalam penelitian ini sebanyak 80 siswi remaja putri. Subyek diambil dengan cara simple random sampling.

Variabel yang digunakan oleh peneliti yaitu variabel dependent dan variabel independent. Variabel dependent dalam penelitian ini yaitu status gizi, sedangkan variabel independent adalah kebiasaan sarapan dan asupan zat gizi. Kebiasaan sarapan dilihat oleh peneliti dari jumlah hari dalam satu minggu responden melakukan makan atau minum di pagi hari sebelum pukul 09.00, asupan zat gizi dilihat dari hasil recall 2×24 jam dengan program Nutrisurvey, sedangkan status gizi ditentukan oleh peneliti berdasarkan pengukuran berat badan dan tinggi badan ( $B B$ dan $T B$ ) dengan menggunakan Body Massa Index (BMI) dengan melihat nilai z-score IMT/U untuk anak perempuan usia 5-19 tahun dengan skor simpang baku (z-score) dengan menggunakan program WHO Anthro Plus 2007.

Analisis data yang dilakukan oleh peneliti untuk mengetahui hubungan antara kebiasaan sarapan dan asupan zat gizi dengan status gizi menggunakan uji Korelasi Spearman yang sebelumnya diuji normalitas datanya dengan uji Kolmogorov-Smirnov.

\section{HASIL DAN PEMBAHASAN}

Responden penelitian sebanyak 80 siswi yang berasal dari kelas $\mathrm{X}$ dan $\mathrm{XI}$ dengan karakteristik responden menurut usia dapat dilihat pada berikut ini.

Tabel 1 dapat diketahui bahwa untuk distribusi usia sebagian besar siswi kelas $X$ dan $X I$ di SMAN 3 Surabaya berusia 16 tahun sebanyak 40 siswi dengan prosentase $50 \%$. Berdasarkan hasil wawancara menggunakan kuisioner dapat diketahui bahwa 59 (73,7\%) siswi memiliki frekuensi makan kurang dari 3 kali dalam sehari. Berikut disajikan distribusi frekuensi makan dan kebiasaan sarapan.

Tabel 1. Karakteristik Responden

\begin{tabular}{llll}
\hline \multicolumn{2}{l}{ Karakteristik } & $\mathbf{n}$ & $\mathbf{\%}$ \\
\hline Usia & & & \\
& 15 tahun & 8 & 10,0 \\
& 16 tahun & 40 & 50,0 \\
& 17 tahun & 31 & 38,8 \\
& 18 tahun & 1 & 1,2 \\
\hline Total & & 80 & 100,0 \\
\hline
\end{tabular}

Tabel 2. Distribusi frekuensi makan dan kebiasaan sarapan

\begin{tabular}{|c|c|c|}
\hline & $\mathrm{n}$ & $\%$ \\
\hline \multicolumn{3}{|c|}{ Waktu Makan yang Dilewatkan } \\
\hline Makan Pagi & 47 & 58,7 \\
\hline Makan Siang & 1 & 1,3 \\
\hline Makan Malam & 32 & 40,0 \\
\hline Total & 80 & 100,0 \\
\hline \multicolumn{3}{|l|}{ Kebiasaan Sarapan } \\
\hline Selalu dilakukan & 31 & 38,8 \\
\hline Kadang-kadang & 30 & 37,4 \\
\hline Jarang & 16 & 20,0 \\
\hline Tidak pernah & 3 & 3,8 \\
\hline Total & 80 & 100,0 \\
\hline
\end{tabular}


Tabel 3. Distribusi Hidangan Sarapan

\begin{tabular}{lll}
\hline Susunan Hidangan Sarapan & $\mathrm{N}$ & $\%$ \\
\hline Susunan Hidangan Sarapan & & \\
$\quad$ Makanan pokok & 24 & 30,0 \\
Makanan pokok+lauk & 34 & 42,5 \\
Makanan pokok+sayur & 8 & 10,0 \\
$\quad$ Makanan pokok+lauk+sayur & 8 & 10,0 \\
$\quad$ Hanya minuman & 6 & 7,5 \\
\hline Total & 80 & 100,0 \\
\hline
\end{tabular}

Tabel 4. Distribusi Asupan Zat Gizi Makro

\begin{tabular}{|c|c|c|}
\hline Asupan Zat Gizi Makro & $n$ & $\%$ \\
\hline \multicolumn{3}{|l|}{ Kecukupan Asupan } \\
\hline \multicolumn{3}{|l|}{ Energi } \\
\hline Adequate ( $\geq 77 \%$ AKG) & 10 & 12,5 \\
\hline Inadequate ( $\leq 77 \%$ AKG) & 70 & 87,5 \\
\hline Total & 80 & 100,0 \\
\hline \multicolumn{3}{|l|}{ Karbohidrat } \\
\hline Adequate ( $\geq 77 \%$ AKG) & 2 & 2,5 \\
\hline Inadequate ( $\leq 77 \%$ AKG) & 78 & 97,5 \\
\hline Total & 80 & 100,0 \\
\hline \multicolumn{3}{|l|}{ Protein } \\
\hline Adequate ( $\geq 77 \%$ AKG) & 32 & 40,0 \\
\hline Inadequate ( $\leq 77 \%$ AKG) & 48 & 60,0 \\
\hline Total & 80 & 100,0 \\
\hline \multicolumn{3}{|l|}{ Lemak } \\
\hline Adequate ( $\geq 77 \%$ AKG) & 27 & 33,7 \\
\hline Inadequate ( $\leq 77 \%$ AKG) & 53 & 66,3 \\
\hline Total & 80 & 100,0 \\
\hline
\end{tabular}

Tabel 5. Distribusi Frekuensi Status Gizi

\begin{tabular}{lll}
\hline Status Gizi & $\mathbf{n}$ & $\mathbf{\%}$ \\
\hline Gizi Kurang & 6 & 7,5 \\
Gizi Normal & 58 & 72,5 \\
Gizi Lebih & 16 & 20,0 \\
\hline Total & 80 & 100,0 \\
\hline
\end{tabular}

Tabel 2 menunjukan bahwa waktu makan yang sering dilewatkan adalah makan pagi yaitu sebanyak 31 siswi $(38,8 \%)$ selalu melakukan sarapan setiap hari namun, masih terdapat banyak siswi yang hanya kadangkadang dan jarang melakukan sarapan. Alasan mereka terkait dengan tidak melakukan sarapan berdasarkan hasil wawancara yang didapat adalah karena takut terlambat ke sekolah, tidak tersedia makanan dirumah, takut sakit perut, tidak sempat karena bangun kesiangan dan lokasi rumah jauh dari sekolah.
Jika dilihat dari susunan hidangan saat sarapan, selengkapnya dapat dilihat pada sebagai berikut.

Tabel 3 menunjukan bahwa susunan hidangan yang dikonsumsi saat sarapan paling banyak yaitu makanan pokok + lauk (42,5\%). Jenis makanan pokok yang sering dikonsumsi oleh responden yaitu nasi goreng, mie instan dan roti tawar. Makanan pokok dan lauk yang sering dikonsumsi sebagian besar yaitu nasi dengan lauk telur dan nasi dengan lauk ayam. Responden yang hanya minum saat sarapan 
sebagian besar mengkonsumsi teh manis, dan susu sereal saat sarapan.

Remaja terutama pelajar sebaiknya sarapan dengan mengkonsumsi makanan yang terdiri dari pangan karbohidrat, lauk-pauk, sayuran atau buah-buahan dan minuman. Bagi orang yang tidak biasa makan kudapan pagi dan kudapan siang, porsi makanan saat sarapan sekitar sepertiga dari total makanan sehari. Bagi orang yang biasa makan kudapan pagi dan makanan kudapan siang, jumlah porsi makanan sarapan sebaiknya seperempat dari makanan harian ${ }^{12}$. Manfaat mengkonsumsi pangan tersebut anatara lain untuk memacu otak agar membantu memusatkan pikiran untuk belajar dan memudahkan penyerapan pelajaran ${ }^{13}$. Pola konsumsi tidak seimbang akan mengakibatkan ketidakseimbangan zat gizi yang masuk ke dalam tubuh yang nantinya dapat menyebabkan gangguan gizi.

Kategori tingkat kecukupan zat gizi dibagi menjadi dua yaitu cukup (adequate) jika $\geq 77 \%$ dan kurang (inadequate) jika $<77 \%$ ${ }^{14}$. Asupan zat gizi yang diteliti adalah asupan zat gizi makro meliputi energi, karbohidrat, lemak dan protein. Asupan zat gizi dapat dilihat pada tabel sebagai berikut.

Tabel 4 menunjukan bahwa sebagian besar siswi belum mencukupi kebutuhan asupan zat gizi makro. Dapat diketahui bahwa rata-rata energi yang dikonsumsi responden remaja putri adalah sebesar 1149,8 Kkal/hari, dimana bila dibandingkan dengan Angka Kecukupan Gizi (AKG) bagi perempuan usia 13-18 tahun yaitu $2125 \mathrm{Kkal}$ maka tingkat kecukupan energi rata-rata remaja putri belum memenuhi standar kecukupan gizi. Rata-rata konsumsi karbohidrat sebesar 135,1 gram/hari, dimana bila dibandingan dengan AKG bagi perempuan usia 13-18 tahun yaitu karbohidrat sebesar 292 gram/hari maka tingkat kecukupan karbohidrat rata-rata remaja putri belum memenuhi standar kecukupan gizi.

Berdasarkan hasil penelitian rata-rata konsumsi protein sebesar 43,3 gram/hari, dimana bila dibandingan dengan AKG bagi perempuan usia 13-18 tahun yaitu protein sebesar 59 gram/hari maka tingkat kecukupan protein rata-rata remaja putri belum memenuhi standar kecukupan gizi. Rata-rata konsumsi lemak sebesar 47,8 gram/hari. Bila dibandingan dengan AKG bagi perempuan usia 13-18 tahun yaitu lemak sebesar 71 gram/hari, maka tingkat kecukupan lemak rata-rata remaja putri belum memenuhi standar kecukupan gizi yang telah dianjurkan. Berikut disajikan distribusi frekuensi status gizi responden

Tabel 5 didapatkan hasil $20 \%$ siswi mengalami gizi lebih dan $7,5 \%$ siswi mengalami gizi kurang. Permasalahan gizi dapat menimbulkan beberapa dampak negatif pada kesehatan. Ketidakseimbangan nutrisi baik kekurangan maupun kelebihan pada remaja mengacu pada gangguan kesehatan seperti risiko penyakit degeneratif, gangguan fungsi pernapasan dan penyakit kardiovaskular bagi yang berstatus gizi lebih. Sedangkan status gizi kurang akan meningkatkan risiko terhadap penyakit terutama penyakit infeksi ${ }^{13}$.

Prosentase status gizi kurang dan gizi lebih pada penelitian ini bila dibandingkan dengan data Riskesdas 2013, angka tersebut telah melebihi prevalensi Provinsi Jawa Timur bagi anak perempuan usia 16-18 tahun kategori kurus dan gemuk, yaitu gemuk 7,7\% dan kurus $5,5 \%$. Selain itu, persentase gizi lebih juga lebih tinggi dibandingkan dengan prevalensi kegemukan di Kota Surabaya yaitu sebesar $12,2 \%{ }^{4}$.

Hasil analisis data untuk mengetahui hubungan antara kebiasaan sarapan dengan status gizi dapat dilihat pada Tabel 6 sebagai berikut.

Berdasarkan analisis data dengan menggunakan uji statistik Spearman Correlation dengan $\alpha=0,05$ menghasilkan nilai $p=0,402$. Menurut hasil statistik menunjukan bahwa tidak ada hubungan yang signifikan antara kebiasaan sarapan dengan status gizi. Meskipun tidak terdapat hubungan secara statistik, berdasarkan hasil analisis dapat diketahui bahwa responden yang selalu melakukan sarapan setiap hari sebagaian besar memiliki status gizi normal. Sedangkan, responden yang tidak pernah sarapan setiap hari sebagian besar memiliki status gizi lebih. Hal ini membuktikan bahwa secara tidak langsung konsumsi sarapan setiap hari dapat 
menekan risiko terjadinya gizi lebih. Penelitian pada remaja di Bogor juga menemukan tidak terdapat perbedaan nyata status gizi pada subjek yang biasa sarapan dengan subjek yang tidak biasa sarapan ${ }^{16}$. Hal tersebut didukung dengan hasil penelitian yang dilakukan oleh Simartama (2014) pada remaja SMA di Kabupaten Samosir yang menunjukkan bahwa semakin baik seseorang sarapan tidak menjamin bahwa status gizi seseorang semakin baik pula ${ }^{17}$.

Berdasarkan hasil penelitian menunjukan tidak ada hubungan yang signifikan antara asupan zat gizi makro (energi, karbohidrat, protein dan lemak) dengan status gizi. Hasil penelitian ini sejalan dengan penelitian Rinanti (2014) pada siswasiswi di Surakarta yang menunjukan tidak terdapat hubungan antara asupan zat gizi makro (energi, karbohidrat, protein dan lemak) dengan status gizi ${ }^{18}$.

Hal tersebut dapat dilihat dari hasil uji statistik hubungan antara asupan energi, karbohidrat, protein dan lemak dengan status gizi yang menghasilkan $p=>0,05$. Berbeda dengan penelitian pada Siswi SMAN 63 Jakarta Tahun 2015 yang menemukan adanya hubungan bermakna antara asupan energi, karbohidrat, protein dan lemak dengan status gizi ${ }^{15}$. Hubungan antara asupan zat gizi energi dengan status gizi dapat dilihat pada Tabel 7 sebagai berikut.

Hasil analisis data dengan menggunakan uji statistik Spearman Correlation dengan $\alpha=0,05$ menghasilkan nilai $p=0,811$. Hasil statistik menunjukan bahwa tidak ada hubungan yang signifikan antara kecukupan energi dengan status gizi. Namun, berdasarkan hasil analisis menunjukan bahwa responden yang memiliki asupan energi sesuai anjuran AKG cenderung memiliki status gizi normal. Hal tersebut dapat dilihat dari persentase status gizi normal pada responden yang memiliki kecukupan energi sebesar 90\%. Hal ini menunjukan bahwa apabila asupan tidak tercukupi kebutuhannya maka akan memiliki peluang yang lebih besar untuk berada pada kategori status gizi kurang. Hubungan antara asupan zat gizi karbohidrat dengan status gizi dapat dilihat pada Tabel 8 sebagai berikut.
Hasil analisis data dengan
menggunakan uji statistik Spearman Correlation dengan $\alpha=0,05$ menghasilkan nilai $\mathrm{p}=0,696$. Hasil statistik menunjukan bahwa tidak ada hubungan yang signifikan antara kecukupan karbohidrat dengan status gizi. Namun, berdasarkan hasil analisis menunjukan bahwa responden yang memiliki asupan karbohidrat sesuai anjuran AKG sebagian besar memiliki status gizi normal. Hal tersebut dapat dilihat dari persentase status gizi normal pada responden yang memiliki asupan karbohidrat cukup sebesar 100\% berstatus gizi normal. Hal ini menunjukan bahwa apabila asupan karbohidrat tidak tercukupi kebutuhannya maka akan memiliki peluang yang lebih besar untuk berada pada kategori status gizi kurang. Hubungan antara asupan zat gizi protein dengan status gizi dapat dilihat pada Tabel 9 sebagai berikut.

Hasil analisis data dengan menggunakan uji statistik Spearman Correlation dengan $\alpha=0,05$ menghasilkan nilai $p=0,970$. Menurut hasil statistik menunjukan bahwa tidak ada hubungan yang signifikan antara kecukupan protein dengan status gizi. Responden yang memiliki asupan protein cukup belum tentu memiliki status gizi normal. Hal ini dilihat dari responden pada kelompok yang mempunyai asupan protein kurang sebagian besar memiliki status gizi normal. Penelitian ini sejalan dengan penelitian Rinanti (2014) pada siswa-siswi di Surakarta yang menunjukan bahwa tidak ada hubungan antara persen asupan protein dengan status gizi ${ }^{18}$. Hubungan antara asupan zat gizi lemak dengan status gizi dapat dilihat pada Tabel 10 sebagai berikut.

Hasil analisis data dengan menggunakan uji statistik Spearman Correlation dengan $\alpha=0,05$ menghasilkan nilai $p=0,816$. Menurut hasil statistik menunjukan bahwa tidak ada hubungan yang signifikan antara kecukupan lemak dengan status gizi. Tidak terdapat adanya hubungan antara kecukupan lemak dan status gizi dapat disebabkan oleh berbagai hal antara lain, porsi makan yang tidak sesuai dengan kebutuhan asupan yang dibutuhkan oleh tubuh. Selain itu, lemak banyak terdapat pada makanan yang bersumber dari hewani, seperti daging 
berlemak, jeroan, kulit dan sebagainya, serta lemak banyak terdapat pada minyak yang sering digunakan saat memasak atau meggoreng.

Hasil penelitian ini tidak sejalan dengan penelitian Muchlisa (2013) pada remaja putri di Makassar yang menemukan adanya significancy 0,002 yang menunjukan bahwa korelasi antara asupan lemak dengan status gizi adalah bermakna ${ }^{19}$. Menurut Savitri (2014) siswi yang memiliki asupan lemak kurang dari anjuran memiliki risiko untuk mengalami status gizi kurang sebesar 1,216 lebih besar dibandingkan dengan siswi yang memiliki asupan lemak sesuai dengan anjuran 15.

Selain asupan zat gizi, faktor lain yang dapat mempengauhi status gizi seseorang diantaranya yaitu jumlah keluarga dan pendapatan keluarga. Hal tersebut yang dapat menyebabkan tidak adanya hubungan antara asupan zat gizi makro dengan status gizi, karena jumlah keluarga yang besar dengan pendapatan keluarga yang relatif rendah dapat mempengaruhi daya beli pangan yang nantinya berpengaruh terhadap kecukupan kebutuhan gizi pada keluarga tersebut.

\section{KESIMPULAN}

Kesimpulan dari penelitian ini yaitu tidak ditemukannya adanya hubungan antara kebiasaan sarapan dan asupan zat gizi dengan status gizi siswi SMAN 3 Surabaya, meskipun secara statistik tidak terdapat hubungan antara kebiasaan sarapan dan status gizi namun siswi yang tidak sarapan memiliki kecenderungan untuk memiliki status gizi lebih dibandingkan dengan siswi yang selalu sarapan setiap hari. Jadi, dibutuhkan pendidikan gizi mengenai pentingnya sarapan agar siswi SMAN 3 Surabaya memiliki kebiasaan sarapan secara teratur. Selain itu, Perlu adanya penelitian lanjut yang serupa antara kebiasaan sarapan dan asupan zat gizi terhadap status gizi dengan memperhatikan faktor-faktor lain seperti aktivitas fisik, penyakit dan infeksi.

\section{ACKNOWLEDGEMENT}

Terima kasih dan penghargaan diberikan penulis kepada seluruh staf pengajar program studi ilmu gizi Universitas Airlangga atas bimbingan dan dukungan yang telah diberikan.

\section{REFERENSI}

1. Adriani, M., Wirjatmadi, B., 2012. Pengantar Gizi Masyarakat. Jakarta: Kencana Prenada Media Group.

2. Haq, A.B., Murbawani, E., 2014. Status Gizi, Asupan Makan Remaja Akhir yang Berprofesi Sebagai Model. Journal of Nutrition College, Vol.3(4).

3. Adriani, M., Wirjatmadi, B., 2012. Peranan Gizi dalam Siklus Kehidupan. Jakarta: Kencana Prenada Media Group.

4. [Riskesdas] Riset Kesehatan Dasar, 2013. Laporan Nasional Riset Kesehatan Dasar (Riskesdas) 2013. Badan Penelitian dan Pengembangan Kesehatan Depkes RI, Jakarta.

5. [Riskesdas] Riset Kesehatan Dasar, 2013. Riset Kesehatan Dasar Dalam Angka 2013 Provinsi Jawa Timur. Badan Penelitian dan Pengembangan Kesehatan Depkes RI, Jawa Timur

6. Hardinsyah, Aries M., 2012. Jenis Pangan Sarapan dan Perannya dalam Asupan Gizi Harian Anak Usia 6-12 Tahun Di Indonesia. Jurnal Gizi dan Pangan, Vol.7(2): 89-96

7. Ethasari, Nuryanto, 2014. Hubungan Antara Kebiasaan Sarapan dengan Kesegaran Jasmani dan Status Gizi pada Anak Sekolah Dasar di SD Negeri Padangsari 02 Banyumanik. Journal of Nutrition College, Vol.3(3).

8. Arifin, Leo A., Prihanto Junaidi, 2015. Hubungan Sarapan Pagi dengan Konsentrasi Siswa di Sekolah. Jurnal Pendidikan Olahraga dan Kesehatan, Vol. 03(01): 203-207.

9. Zuhdy, Nabila, 2015. Hubungan Pola Aktivitas Fisik dan Pola Makan dengan Status Gizi pada Pelajar Putri SMA Kelas 1 di Denpasar Utara. Tesis. Universitas Udayana. Denpasar

10. Widianti, Nur, 2012. Hubungan Antara Body Image dan Perilaku Makan dengan 
Status Gizi RemajaPutri di SMA Theresiana Semarang. Artikel Penelitian Program StudillmuGizi FK. Universitas Diponegoro. Semarang

11. Rosyidah, Z., Andrias,D.R., 2015. Jumlah Uang Saku Dan Kebiasaan Melewatkan Sarapan Berhubungan dengan Status Gizi Lebih Anak Sekolah Dasar. Media Gizi Indonesia, Vol.10(1): 1-6.

12. [KEMENKES RI] Kementerian Kesehatan Republik Indonesia, 2014. Pedoman Gizi Seimbang. Kemenkes RI, Jakarta

13. Larega, Tanika Sonia, 2015. Pengaruh Sarapan Terhadap Tingkat Konsentrasi pada Remaja. Artikel Review J MAJORITY, Vol. 4(2).

14. Gibson, R.S., 2005. Principle of Nutritional Assesment Second Edition. New York: Oxford University Press.

15. Savitri, Wulan, 2015. Hubungan Body Image, Pola Konsumsi dan Aktivitas Fisik dengan Status Gizi Siswi SMAN 63 Jakarta Tahun 2015. Skripsi. Universitas Islam Negeri Syarif Hidayatullah. Jakarta

16. Niswah,I, Damanik,M.R dan Ekawidyani,K.R., 2014. Kebiasaan Sarapan, Status Gizi, dan Kualitas Hidup Remaja
SMP Bosowa Bina Insani Bogor .Jurnal Gizi dan Pangan, Vol.9(2): 97-102.

17. Simarmata, Rotua Y., 2014. HubunganKebiasaan Sarapan dengan Status Gizi dan Prestasi Siswa SMA N 1 Pangururan KabupatenSamosir. Skripsi. Institut Pertanian Bogor. Bogor

18. Rinanti, OkkySetyaning, 2014. Hubungan Asupan Zat Gizi Makro dan Pengetahuan Gizi Seimbang dengan Status Gizi SiswaSiswi di SMP Muhammadiyah 1 Kartasura. TugasAkhir. Universitas Muhammadiyah Surakarta. Surakarta.

19. Muchlisa, Citrakesumasari \&Indriasari, 2013. Hubungan Asupan Zat Gizi dengan Status Gizi pada Remaja Putri di Fakultas Kesehatan Masyarakat Universitas Hasanuddin Makassar Tahun 2013. Jurnal online. Diakses di http://repository.unhas.ac.id/handle/123 456789/5487pada 10 Juli 2017 pukul 08.11.

20. Pujiatun, Tri, 2014. Hubungan Tingkat Konsumsi Energi dan Protein dengan Kejadian Kurang Energi Kronis (KEK) pada Siswa Putri di SMA Muhammadiyah 6 Surakarta. Skripsi. Universitas Muhammadiyah. Surakarta. 